\title{
Rethinking the Role of Pedagogical Assistants: Establishing Cooperation between Roma Families and Schools in Serbia
}

\author{
Jelena Starčević ${ }^{* 1}$, Bojana Dimitrijević ${ }^{2}$ And \\ Sunčica Macura Milovanović ${ }^{3}$
}

$\approx$ The aim of the present paper is to examine the risks and challenges related to the cooperation of pedagogical assistants (PAs) with Roma parents/ families and their work with Roma pupils, as well as to offer further insight into ways to overcome these risks and challenges. Roma pupils and parents/families face numerous difficulties in education, which are reflected in prejudice, stereotypes and discrimination. The education policy measure of introducing PAs, formerly known as Roma teaching assistants, to the Serbian education system aimed to contribute to the learning and social participation of Roma pupils and to establish cooperation between school staff and Roma parents. The further segregation of Roma pupils and the reduced engagement of teachers in supporting Roma pupils and fostering communication with Roma parents are seen as possible risks related to the engagement of PAs. In order to minimise the risks, we propose a framework for defining and understanding the roles of teachers and PAs from an intercultural perspective. Relying on two concepts - intercultural sensitivity (IS) and intercultural competence (IC) - we elaborate the necessity of perceiving cultural differences in accordance with an ethnorelative worldview, on the part of both teachers and PAs. In addition, we outline the cognitive, affective and behavioural aspects of IC that we believe teachers and PAs should possess. Further recommendations regarding the engagement of PAs and the minimisation of risks and challenges are proposed.

Keywords: Roma teaching assistants/pedagogical assistants, teachers, Roma pupils/families, intercultural sensitivity, intercultural competence

$1 \quad{ }^{\star}$ Corresponding Author. Faculty of Education, University of Kragujevac, Serbia; jelenas.psi@gmail.com.

2 Faculty of Education, University of Kragujevac, Serbia.

3 Faculty of Education, University of Kragujevac, Serbia. 


\section{Premišljevanje vloge pedagoškega asistenta - vzpostavljanje sodelovanja med romskimi družinami in šolami v Srbiji}

Jelena Starčević, Bojana Dimitrijević in

Sunčica Macura Milovanović

$\approx$ Namen prispevka je preučiti nevarnosti in izzive, povezane s sodelovanjem pedagoških asistentov (PA), z romskimi starši/družinami in njihovim delom $\mathrm{z}$ romskimi učenci ter omogočiti vpogled $\mathrm{v}$ načine, s katerimi se je mogoče spoprijeti s temi nevarnostmi in izzivi. Romski učenci in starši/družine se spoprijemajo s številnimi težavami v izobraževanju, ki se odražajo v predsodkih, stereotipih in v diskriminaciji. Ukrep s področja edukacijske politike, ki je v srbski izobraževalni sistem vpeljal pedagoške asistente (PA), prej imenovane "pomočniki učitelja za delo z romskimi učenci«, je vpeljan s ciljem prispevati k učenju in družbeni participaciji romskih učencev ter $\mathrm{k}$ vzpostavitvi sodelovanja med šolskim osebjem in starši romskih učencev. Nadaljnja segregacija romskih učencev in zmanjšan angažma učiteljev pri podpori romskim učencem ter slabše spodbujanje komunikacije s starši romskih otrok so v prispevku prepoznani kot potencialne ovire pri delu PA. Da bi te ovire zmanjšali, predlagamo okvir za opredelitev in razumevanje vloge učiteljev in PA z vidika medkulturne perspektive. Ob opori na dva koncepta, tj. medkulturno občutljivost (MO) in medkulturne kompetence (MK), pojasnjujemo potrebo po dojemanju kulturnih razlik skladno z etnorelativnim pogledom na svet $z$ vidika učiteljev kot PA. Poleg tega poudarjamo kognitivne, emocionalne in vedenjske vidike $\mathrm{MO}$, za katere verjamemo, da bi jih morali posedovati učitelji in PA. Predlagamo tudi nadaljnja priporočila glede angažmaja PA ter zmanjševanja nevarnosti in izzivov.

Ključne besede: pomočniki učitelja za delo $\mathrm{z}$ romskimi učenci/ pedagoški asistenti, učitelji, romski/-e učenci/družine, medkulturna občutljivost, medkulturne kompetence 


\section{Introduction}

In Serbia, as in the other countries of the Western Balkans and Southeast Europe, the most vulnerable and disadvantaged communities belong to the Roma minority (Save the Children, 2001). Roma are the poorest and most endangered social group in Serbia. World Bank estimates suggest that 60.5 percentof the Roma population falls within the category of "very poor", compared with 6.1 percent of the total population. In Serbia, as in other countries of the region, Roma face racial prejudice, social exclusion and widespread discrimination in access to housing, employment and social welfare, health and education (Bennett, 2012, p. 98). Their education level is extremely low: 21 percent have no education, 34 percent have not completed primary education, 33 percent have primary education, 11 percent have secondary education and only 0.7 percentof Roma have higher education (Radovanović \& Knežević, 2014). The proportion of Roma children reaching the last grade of primary school is 85.9 percent, while 15 percent remain outside the education system (Statistical Office of the Republic of Serbia, 2014). Although the percentage of Roma pupils in special schools is decreasing every year, they are still over represented in special education and constitute almost one fifth of all pupils in special schools (European Roma Right Centre, 2014).

One of the strategies that can contribute to improving Roma education is built on involving Roma parents/families in their children's schooling. The results of studies (Desforges \& Abouchaar, 2003; Crozier \& Davies, 2007; Knowles \& Holmstrom, 2013) indicate that family involvement in school improves children's achievements. In addition, dialogue and communication between parents/families and school contribute to resolving both behavioural and academic problems. However, Roma parents do not trust the educational institutions that have to care for their children (Flecha \& Soler, 2013, p. 454). From the perspective of Roma parents, the major problems in their children's schooling are rooted in ethnocentric schools, discrimination and the low quality of instruction (Macura-Milovanović, 2012).

The lack of trust and the vulnerability of Roma in their contact with schools is a consequence of widespread stereotypes and prejudice, as well as of the discrimination that many Roma have experienced during their education. One of the common prejudices that contributes to Roma educational exclusion is related to Roma's so-called natural disaffection with school, e.g., the idea that Roma exclude themselves from mainstream education in order to preserve their culture. As reported by Flecha and Soler (2013), Roma researchers Hancock and Rose question these assumptions, arguing that they are used by non-Roma to 
keep Roma on the margins of society. Gomez and Vargas (2003) also conclude that school disaffection can be explained by the ethnocentric perspective of school. Mainstream schools do not consider engaging in dialogue with Roma families, who end up perceiving school as an institution of the non-Roma world (Flecha \& Soler, 2013, p. 453).

In the opinion of teachers, the difficulties of Roma pupils in schools (such as irregular attendance, etc.) are related to the context outside school family, social situation, culture - or to the Roma pupil him/herself - lack of norms, lack of interest. When explaining the cause of Roma pupils' difficulties, teachers hardly ever allude to factors related to the actual role of the teacher (Gimenez Adelantado, Piasere \& Liegeois, 2002, p. 77). Similarly, when explaining the causes of Roma pupils' under achievement, teachers offensively point to Roma parenting competencies, labelling them as "undeveloped". The ethnocentric perspective and the position of cultural superiority of majority-population teachers leads to advocating the need for the Roma minority to accept the values and identity of majority society as a basic precondition for achieving success in education. The key missing element in the overall school perception of the Roma family is an understanding of the importance of the trust relationship with Roma parents and children (Macura-Milovanović, 2012).

Roma families are often perceived as a risk to the status of the school, because they do not have the knowledge, contacts, confidence, time and money to invest in their children and thereby promote high educational performance. Therefore, as Lunch and Baker (2005) state, "the failure of schools to acknowledge the cultural dissonance that exists between their mores and practices and those of students from diverse ethnic and racial backgrounds exacerbates their educational failure and their sense of alienation from the education process itself" (p. 19).

One way of bridging this cultural dissonance, as well as improving Roma pupils' school achievements, is seen in establishing the position of Roma teaching assistants (RTAs). In many countries that are struggling to overcome the barriers that Roma pupils face in school, education policy measures involve, inter alia, engaging RTAs. Guidelines on inclusive early childhood care and education for Roma children (UNESCO and the Council of Europe, 2014) envisage that "official recognition of RTAs is seen as one of the rare success stories about Roma education. In most cases, they have been effective bridges between Roma families and the school and instrumental in increasing school enrolment and retention of Roma pupils in the education system" (p. 43).

However, the position of RTAs is also perceived as a "double edged sword". As Vandenbroeck remarks (2011), the model of Roma assistant/majority teacher reproduces the social inequality that prevails between the Roma 
minority and the mainstream population. In addition, there seems to be an evident paradox: education policymakers have delegated the most complex and demanding tasks (such as establishing cooperation with "hard to reach" parents, reducing the dropout rate, preventing discrimination towards minority pupils, etc.) to RTAs, who are less qualified than teachers. There is an underlying assumption, as Vandenbroeck (2011) notes, that in order to establish cooperation with Roma parents, one needs to share a similar background. This may lead teachers to conclude that there is no need to try to overcome the communication gap with poor minority groups, or provide them with an excuse to avoid direct communication with the Roma community.

Bearing in mind the contested nature of the position of RTAs/PAs in education systems, in the present paper we aim to answer the following questions: What are the risks and challenges related to the cooperation of PAs with Roma families and their work with Roma pupils? How could these risks be overcome, or at least minimalized? A further aim of the article is to propose a framework for defining and understanding the roles of teachers and PAs in working with Roma. In the next subsection, we will first analyse how the role of PAs is conceived legislatively, and how it is implemented in the practice of educational institutions in Serbia.

\section{The role of PAs: Legislative foundation and realisation in school practice}

The specific role and profession of pedagogical assistants in Serbia have been developing for nearly 20 years. The socio-political context that allowed and supported the establishment of the new position in the education system was grounded in policy documents such as A Decade of Roma Inclusion 2005-2015, the Strategy for the Improvement of Roma Status in Serbia (2009), and the new Law on the Foundations of the Education System (LoF) (2009), as well as on financial support from the Fund for an Open Society, the Organisation for Security and Co-operation in Europe (OSCE), the Roma Education Fund, and others. The introduction of RTAs commenced in 1996, largely with support from the Fund for an Open Society, based on the "Step by Step" methodology. In 2006, the Ministry of Education (MoE) and the OSCE initiated the project Support to the Ministry of Human and Minority Rights for Coordination Programmes for Roma, which was specifically aimed at introducing RTAs into primary school education.

In 2009, within new education legislation (LoF, 2009) that introduced inclusive education in Serbia, the position of RTAs was legally established and their title was changed to pedagogical assistant (PA). According to LoF, the 
role of a PA consists of four basic tasks: 1) providing assistance and additional support to children and pupils in accordance with their needs, 2) providing support to teachers and preschool teachers, as well as to school psychologists/ pedagogues, with theaim of improving their work with children/pupils who need additional support, 3) establishing cooperation with parents/caregivers, and 4) together with school principals, establishing cooperation with relevant institutions and the local community (Article 117). It is interesting to note that, although the PA is delegated such highly professional pedagogical tasks, he/she does not need a work license (Article 122). Since a licence (which can be obtained by passing the official "licence exam") confirms professional competencies, in practice the absence of a licence means that the education system is not officially verifying the professional readiness of PAs to work with pupils, teachers, parents, etc. Furthermore, PAs may participate in the work of the school council, but they have no right to participate in decision making (Article 132).

PAs are engaged in schools and preschool institutions with a significant proportion of Roma pupils, and in most cases they belong to the Roma national minority as well, which is indirectly defined by the Rulebook of the Training Programme for PAs (2010). According to the Rulebook, a necessary precondition for the position of PA, besides a certificate of secondary education, is a knowledge of Roma language. There are currently 174 PAs employed in schools and preschool institutions in Serbia. Their salaries are lower than those of teachersand they have a working contract with the school for 12 months, with no possibility of permanent employment.

Several studies have attempted to evaluate the results of RTA/PA engagement since their introduction in the Serbian education system. The most comprehensive analyses of RTA engagement is provided in the Evaluation Study: The Role of Pedagogical Assistants for the Support of Roma Students by the Institute for the Evaluation of Education Quality (IEEQ, 2009). This study was carried out in 22 primary schools on a sample of 657 teachers, parents, pupils and school staff, including 24 RTAs engaged in the schools. The results of the study indicated that although the role of the RTAs was invaluable and successful (approximately 91 percent of Roma pupils improved their school achievements after Roma assistants were introduced), teachers did not engage in collaborative classroom teamwork with them. RTAs mostly carried out work with a Roma pupil or with a group of Roma pupils during remedial classes. In addition, the study indicates that the role of RTAs in cooperation with Roma families is mainly limited to home visits aimed at informing Roma parents about their children's achievements in school or gathering information about children that should be enrolled in the first grade and motivating families to enrol their 
children. However, there is an evident lack of work on the empowerment of Roma families to take on a more proactive role in supporting their children in education, or on the further education of Roma parents.

The Study of Roma Pedagogical Assistants as Agents of Change (Duvnjak et al., 2010) analysed the role of RTAs on a sample of 29 assistants and 53 school representatives. The results of the study suggest that both groups of respondents agree that assistants devote the most working hours to working with pupils, followed by cooperation with Roma families, while cooperation with relevant institutions and the local community is in third place. However, the authors point out that there is a risk of assistants working on tasks that teachers regard as being beyond their traditional role (e.g., organising activities in Roma settlements, providing support for collecting personal documentation, revealing cases of discrimination of Roma pupils). In some cases, teachers do not want to work on cooperation with Roma families and provide support for learning (Duvnjak et al., 2010, p. 46). Another interesting study, entitled Assessment of Teachers' Capacities and Needs for the Development of Inclusive Education, undertaken with 811 teachers (Đelić et al., 2012), reported that only 10 percent of respondents stated that assistants are engaged in cooperation with the family, while 16 percent stated that they are engaged in providing meals, cloths and other material preconditions for the education of Roma pupils.

A recent case study analysing the role of the PA in a small primary school located in a remote settlement (Milovanović, 2014) draws attention to certain short comings in the realisation of the PA's role, such as the PA's lack of support for Roma pupils in the fifth grade, the lack of cooperation between the PA and teachers in planning activities, etc. Milovanović emphasises that the PA does not participate in extracurricular activities in school. "For this reason, the PA does not contribute to developing intercultural relations and a climate of mutual trust and respect within the school and the local community" (Milovanović, 2014, p. 64). However, it is important to note that the author stresses that these shortcomings are consequences of weak management of the PA in the school and the school's (lack of) organisation, and do not result from thePA's lack of competence.

In summing up the major challenges and risks of the PA role, we may state the following: 1) The introduction of PAs provides license for teachers to neglect Roma pupils, allowing PAs to actually teach these pupils, contrary to their officially more limited support role (Macura-Milovanović, Pantić and Closs, 2012, pp. 20-21). Although unintentionally, the work of PAs may provoke the segregation of Roma pupils within the class or school, because the PA and Roma pupil(s) become a special group within the class. In this case, there is a risk of scarce communication between Roma pupils and their peers 
and/or teacher. 2) Some PAs perform additional tasks that are not defined by the LoF; on the other hand, they are not fully accomplishing the tasks that are delegated by the LoF. Even the most professional and skilful PA will be ineffective in aschool with a culture that is not inclusive and with teachers who lack competencies for teamwork and believe that Roma pupils and families are the responsibility of Roma assistants, for whatever reason.

\section{Quality education for Roma: The roles of teachers and PAs from an intercultural perspective}

Bearing in mind the aforementioned risks and short comings, as well as the insufficiently utilised benefits of the engagement of PAs, we sought to find new ways to define and understand the roles that both teachers and PAs should undertake. The choice of the intercultural paradigm seemed reasonable because work with Roma families and Roma pupils is by definition intercultural. Intercultural communication occurs in many directions: between teachers and Roma pupils, between teachers and PAs, and between PAs and non-Roma pupils, as well as with parents and the local community. Work with Roma is marked by differences in language and culture, but also by stereotypes and prejudice. In this regard, we were interested in the qualities of teachers and PAs that are deemed important in intercultural communication following two different approaches to this issue.

The first approach reflects the developmental perspective. McAllister and Irvine (2000) suggested three developmental models as a frame of reference for teachers' multicultural education and acquiring cross-cultural competence: the Model of Racial Identity, the Typology of Ethnic Identity, and the Developmental Model of Intercultural Sensitivity (DMIS) (Bennett, 2011). The latter, however, has two main advantages compared to the other two: it is the most elaborated and the most empirically supported model (e.g., Hammer, 2011; Paige, Jacobs-Cassuto, Yershova, \& DeJaeghere, 2003; Westrick, 2004; Zhang, 2014). We therefore used Bennett's model of change from an ethnocentric to an ethnorelativist worldview as a basis for the delineation of teachers' and PAs' required level of intercultural sensitivity.

The second approach rests on the complex construct of intercultural competence (IC), which seems to prevail in studies of the traits and capacities considered essential for successful intercultural interaction. This approach is closely connected with the aforementioned intercultural sensitivity; according to Bennett (2004), "greater intercultural sensitivity creates the potential for increased intercultural competence" (p. 73). The three dimensions of IC 
- cognitive, affective and behavioural (Chen \& Starosta, 1996; Deardorff, 2006; Prechtl \& Lund, 2007) - served as a frame of reference for defining teachers' and PAs' core competencies for working with Roma. At the same time, this framework corresponds to the definition of teachers' professional competencies in Serbian legal documents as a set of necessary knowledge, skills and attitudes (LoF, 2009; Rulebook of Competency Standards for Teachers in Serbia, 2011).

\section{Intercultural sensitivity of teachers and PAs}

Dealing with cultural differences along the continuum ethnocentrism ethnorelativism, the DMIS defines a qualitative change of experience through the gradual transformation of one's worldview through six different stages: denial, defence, minimisation, acceptance, adaptation and integration (Bennett, 1986, 1998, 2004; Bennett \& Bennett, 2004). According to Bennett, "as categories for cultural difference become more complex and sophisticated, perception becomes more interculturally sensitive" (Bennett, 2004, p.73). It is important to note that the DMIS is not a model of change of behaviour or attitudes; it is rather a model of development of cognitive structure (Bennett \& Bennett, 2004), while behaviours and attitudes could be understood as indicators of the specific underlying worldview. In the present paper, we therefore present our expectations regarding manifestations of the different stages of intercultural sensitivity of teachers and PAs in the specific school context. We propose the argument that, both in the case of teachers and PAs, the characteristics of an ethnocentric worldview should be transcended in order to establish the possibility of successful intercultural communication.

According to Bennett, the first stage of the DMIS is the denial of cultural differences, which represents the purest form of the ethnocentric worldview (Bennett, 1986, 2004). Teachers and PAs in this stage would assume that all pupils/parents/colleagues share the same beliefs, behavioural norms and values. A teacher in the stage of denial would not perceive cultural differences between the pupils/parents as cultural at all, and would construct very broad cognitive categories for differences ("minorities" or "others"). Encounters with differences would be disturbing for teachers and PAs in this stage. During interaction with Roma parents or pupils, the teacher would express excessive politeness or would avoid cultural differences. This could result in delegating the task of maintaining communication and cooperation with Roma families to PAs. Teachers in this stage would not be able to integrate the intercultural perspective into lesson planning or use culturally appropriate material and content, nor would they be able to support pupils and families, due to the fact that they 
would not be aware of the relevant differences. PAs in the denial stage could have difficulties cooperating with teachers and other school staff of the majority cultural background, possibly avoiding unnecessary interaction and focusing on working with Roma pupils and the Roma community.

In the second stage of the DMIS, the stage of defence, teachers and PAs are capable of perceiving certain differences as cultural, but the categories formed in this process would be general ("Roma", "Serbian", etc.) (Bennett, 1986, 2004). The Roma cultural group would be perceived by teachers as inferior in comparison to their own. Stereotypical thinking about Roma pupils and parents could be represented in a tendency to uncritically assign the same characteristics to most of those who are perceived as Roma ("talented musicians" or "uninterested in schooling"). Teachers could possibly negatively evaluate and overemphasise differences, interpreting them as the cause of lower learning achievement or difficulties in establishing cooperation with some Roma parents. PAs could evaluate their own cultural group as inferior, while stressing the superiority of the majority cultural group in a simplified and generalised manner, which is are versed form of defence (Bennett, 1986, 1998, 2004). In comparison to the Roma population in general, PAs have higher levels of education and cooperate with school staff, which could contribute to identification with the majority group.

In the third stage of the DMIS, the stage of minimisation of cultural differences, a person is able to perceive some differences as cultural, while at the same time focusing on human commonalities: biological universals or "transcendent" principles (Bennett, 1986, 1998, 2004). The minimisation stage represents a significant developmental advancement regarding the perception of minority pupils/families. The latter are perceived as similar to any other group of pupils/parents, and observed cultural differences are not negatively evaluated. Teachers and PAs in this stage would probably assume that all pupils have similar needs/concerns and that the same forms of support are adequate for all Roma pupils/parents. This could be particularly important when a situation is ambiguous for a teacher/PA and when their interpretation of the situation does not take into account the perspective of the Roma pupil/parent.

The fourth stage of the DMIS, acceptance of cultural differences, represents the first ethnorelative stage of the development of IS. Acceptance is characterised by the perception of one's own worldview as just one of many equally complex worldviews (Bennett, 1986, 2004; Bennett \& Bennett, 2004). In this stage, behavioural differences of Roma pupils/parents would be perceived and recognised as a reflection of cultural values, both by the teacher and the PA. Cultural values would be perceived as a process of assigning meaning and value to situations and would not be evaluated according to the standards of the 
majority cultural group as "adequate" or "inadequate". Teachers and PAs would not assume that cultures "have" values and that values are "transferred" to all members of a particular cultural group.

Language differences would be perceived as an expression of different ways of organising reality, rather than simply different ways of marking/naming the same phenomena. Teachers and PAs would be aware of the fact that Roma pupils organise their thoughts in oral or written form differently than majority cultural group members, even if they are fluent speakers of the language of schooling. Communication and learning style, as well as nonverbal behaviour, would be interpreted as an expression of deeper cultural differences. Teachers and PAs would understand that their perception and interpretation of the same phenomenon is culture-relative, which is an expression of their cultural self-awareness.

Differences would not be threatening for the teachers and PAs, as their own worldview would not be compromised when they were faced with different behavioural norms and values. They would be able to tolerate ambiguous situations that include pupils/parents/colleagues of a different cultural background. PAs and teachers in this stage would be interested in understanding the others' point of view regarding the same school-related issue, and would seek to develop strategies for cooperation.

Intercultural sensitivity continues to evolve through the stage of adaptation, which is characterised by the expanding ability "to use the acceptance of cultural difference" (Bennett, 1986, p.51), applying knowledge, skills and perception of cultural difference in intercultural interaction. Although this ability would be beneficial for working in a heterogeneous context for both teachers and PAs, it would require intense and prolonged experience of immersion in a different cultural context, e.g., a foreign country. The same is true ofthe sixth and final stage of the DMIS, integration, which concerns issues of construction of identity on the margins of more than one culture (Bennett, 2004). A plausible expectation of teachers and PAs would require them to perceive cultural differences in accordance with the ethnorelativist worldview of the acceptance stage as a basis for the further development of sensitivity and competence.

\section{Intercultural competence of teachers and PAs}

After several decades of research, intercultural scholars reached agreement on the essence of IC: it is "the ability to communicate effectively and appropriately in intercultural situations based on one's intercultural knowledge, skills, and attitudes" (Deardorff, 2006, pp. 247-248). Cognitive, affective and behavioural components are usually present in IC models and associated 
constructs (Ang et al., 2007; Chen \& Starosta, 1996; Prechtl \& Lund, 2007; Ward, 2001), reflecting the complexity of intercultural interaction and the numerous demands this interaction imposes.

The Rulebook of Competency Standards for Teachers in Serbia (2011) alleges only few competencies of direct relevance to working with pupils from different cultural groups: (a) teachers need to know and understand social and cultural differences between pupils, and (b) teachers need to know how to support pupils from vulnerable social groups. The Rulebook, however, states a larger number of teacher competencies that may contribute to successful intercultural interaction in the school system (e.g., planning activities according to the experience of pupils, possessing knowledge of successful communication techniques).

We used models of IC in general as well as models of teacher's IC (Banks, 2006; Gay \& Howard, 2010), along with the description and analyses of PA activities (IEEQ, 2009; Kyuchukov, 2012; Rulebook of Training Programme for PA, 2010; Rus, 2004, 2006), as a frame of reference for defining what teachers and PAs should possess in order to work effectively with Roma. We chose this method in order to indicate the elements of all three components of IC: the cognitive component refers to cultural knowledge and the metacognitive and cognitive abilities applied to intercultural interaction; the affective component refers to motivation, appropriate attitudes and positive emotions evoked by intercultural interaction; finally, the behavioural component refers to outward manifestations or overt actions, including communication skills and a large part of classroom activities. Some IC elements represent a combination of these components, but they can still be classified on the basis of their predominant domain.

Table 1. IC of teacher and PA: Cognitive component

\begin{tabular}{ll}
\hline \multirow{2}{*}{ Roles } & Intercultural competence \\
\cline { 2 - 2 } $\begin{array}{ll}\text { Teacher } \\
\text { and PA }\end{array}$ & $\begin{array}{l}\text { Cognitive Component } \\
\text { understand the impact of poverty and marginalisation on children's development } \\
\text { and people's lives; know ways to reduce barriers in intercultural interaction and } \\
\text { fight discrimination; possess cultural self-awareness and a capacity for self- } \\
\text { regulation; possess the ability to decentrate from the one's own point of view; } \\
\text { know about cultural values, norms and customs; understand others' worldviews; } \\
\text { understand how culture affects thought, behaviours and patterns of life; know how } \\
\text { pupils organise their thoughts in verbal and written form; know how pupils learn } \\
\text { best; know the principles and strategies of individualised work }\end{array}$ \\
\hline Teacher & $\begin{array}{l}\text { knows how to create a climate and community conducive to development and } \\
\text { learning for all pupils; knows multiple ways to adapt the curriculum, learning activi- } \\
\text { ties and assessments }\end{array}$ \\
\hline PA & \begin{tabular}{l} 
additional requirements are not necessary \\
\hline
\end{tabular}
\end{tabular}


Table 2. IC of teacher and PA: Affective component

\begin{tabular}{ll}
\hline \multirow{2}{*}{ Roles } & Intercultural competence \\
\cline { 2 - 2 } & Affective Component \\
\hline Teacher & $\begin{array}{l}\text { appreciate different patterns of life, different views and ideas; are motivated to establish } \\
\text { and }\end{array}$ \\
PA & and maintain intercultural contact; enjoy their duties in an intercultural context; possess \\
\hline Teacher & additional requirements are not necessary \\
\hline PA & additional requirements are not necessary \\
\hline
\end{tabular}

Table 3. IC of teacher and PA: Behavioural component

\begin{tabular}{ll}
\hline \multirow{2}{*}{ Roles } & Intercultural competence \\
\cline { 2 - 3 } $\begin{array}{l}\text { Teacher } \\
\text { and }\end{array}$ & $\begin{array}{l}\text { pehavioural Component } \\
\text { PA }\end{array}$ \\
& $\begin{array}{l}\text { all important information about the children's development; empower families to } \\
\text { participate and take a proactive role in the children's education; talk in a way that } \\
\text { pupils and families can understand; use descriptive communication messages (avoid } \\
\text { judgements); manifest self-reliance, perseverance and reliability; display empathy and } \\
\text { warmth; protect pupils and families from prejudice and discrimination; promote posi- } \\
\text { tive social values; provide conditions for regular school attendance; provide additional } \\
\text { support to pupils' understanding during regular classes; provide additional support for } \\
\text { the accomplishment of learning activities within schoolwork and homework; organise } \\
\text { cooperative learning between pupils; use culturally relevant and authentic learning } \\
\text { material; create equitable, culturally appropriate and authentic learning activities; use } \\
\text { equitable achievement measures; work in a team to prepare, accomplish and evalu- } \\
\text { ate an individual educational plan; prepare pupils for standardised testing and other } \\
\text { academic activities; support pupils' engagement in extracurricular school activities; } \\
\text { collaborate with school staff in order to support pupils and families; collaborate with } \\
\text { relevant institutions and organisations in order to support pupils and families }\end{array}$ \\
\hline $\begin{array}{l}\text { creates a supportive classroom environment; encourages understanding and support } \\
\text { among parents; matches teaching style and instructional techniques to the pupils' } \\
\text { needs; provides equitable and valid assessment; provides culturally sensitive extra- } \\
\text { curricular school activities }\end{array}$ \\
\hline $\begin{array}{l}\text { Teacher } \\
\text { speaks Romani; supports and assists families with school enrolment; assists in pupils' }\end{array}$ \\
\hline PA
\end{tabular}

\section{Overlaps and differences: Clarifying the roles of teachers and PAs in respect to working with Roma}

In the previous section, we presented the level of intercultural sensitivity that teachers and PAs should possess, as well as the elements of their IC. The aim was to clarify and deepen the understanding of the roles of teachers and PAs regarding their professional engagement with Roma pupils and families.

First of all, it is important to clarify the fact that teachers need to be at the established level of IS and must possess all of the listed elements of IC whether they collaborate with PAs or not. In essence, these requirements are 
part of the teachers' professional competencies, i.e., teaching, assessment, communication and other professional activities of teachers. In addition, bearing in mind the differences between the employment conditions and professional status of teachers and PAs (Kyuchukov, 2012; Rus, 2004), it would be unrealistic to expect that PAs alone could achieve the set goals without collaboration with interculturally sensitive and competent teachers (as well as principals and other school staff). It is also important to stress that the established level of intercultural sensitivity and IC of teachers are also necessary for working with pupils and families from any other cultural group. This appears to be the case with the activities of PAs, but to a lesser extent.

As argued above, teachers should be characterised by the same level of intercultural sensitivity as PAs, i.e., at least the stage of acceptance of cultural differences. The previous stages and the underlining assumptions, perceptions, and behavioural and emotional reactions to cultural differences are clearly inadequate for the role of teacher. Even the minimisation stage presupposes a lack of understanding of pupils, and particularly Roma families, which creates doubts about the quality of support these teachers can provide to pupils' academic progress and social participation. If teachers strive for a more complete understanding of pupils and families, in addition to aiming at skilful teaching and successful communication, their intercultural sensitivity needs to develop towards the ethnorelativist part of the spectrum.

Tables 1-3 show that teachers and PAs have a very similar IC profile. Although they share many IC elements, this does not mean that they should possess the same levels of knowledge, or should apply the same skills with the same frequency, etc.; it simply means that all of these elements should be part of their competencies. For example, teachers should care about pupils' homework and regular attendance, even if these activities are one of the well-defined activities of PAs. In other words, teachers need to remain teachers for Roma as well as for non-Roma pupils. The same tables reveal the differences between certain elements of the IC of teachers and PAs. These differences are mainly associated with the teachers' unique qualifications and job description (e.g., their knowledge of teaching methodology and classroom management), and PAs can only assist in these activities if teachers organise their involvement. Much the same applies to working with non-Roma parents as well as PAs' participation in parent meetings. Although PAs might be helpful in these activities, according to the regulations at least, it is the teacher who should have the main role. Finally, there are very few IC elements relevant only to PAs, the most prominent being a knowledge of Roma language.

The significant overlap of the roles of teachers and PAs prompts the question as to why schools engage PAs. The reason for engaging a PA is evident only 
in those cases where families do not speak the language of schooling (or possess a very limited knowledge of that language).The reason is not, however, as evident in all other cases, providing teachers possess the recommended level of intercultural sensitivity and elements of IC. Research of teachers' intercultural sensitivity indicates that most teachers perceive cultural differences in accordance with an ethnocentric worldview (Leutwyler et al., 2014; Yuen, 2010). It could therefore be said that the employment of PAs most often reflects the failure of the school to provide quality education for pupils from vulnerable groups.

Below we posit the recommendations regarding the engagement PAs derived from considerations of the risks it brings, as well as from an analysis of the roles of teachers and PAs from an intercultural perspective.

1. The engagement of PAs should be guided by the goals and principles of inclusive education, fostering real participation of Roma pupils and families. Support for learning activities of Roma pupils should be provided during regular classes as much as possible.

2. The activities of PAs should be determined so as to focus on goals that are relevant to Roma (e.g., academic achievement, good social relationships, nurturing cultural identity).

3. The activities of PAs should be tailored in accordance with their qualifications, employment conditions and school status. PAs cannot replace teachers; their role should be only supportive, but with ample possibilities to contribute to the teaching process and other school activities.

4. The activities of PAs should be more appropriately planned and organised within schools so as to take into account the primary goals of the engagement of PAs and the risk of overload (Rus, 2004).

5. Special attention should be given to developing cooperation between teachers and PAs. School staff (psychologists, pedagogues, principals) should provide support for this process. Teachers should be acquainted with their responsibilities and understand their role when they cooperate with PAs. It is strongly advisable that teachers perceive their collaboration with PAs as an opportunity to develop their own competencies for working with Roma.

\section{Conclusions}

The present paper deals with the risks and challenges related to the engagement of PAs with Roma families/pupils, as well as ways of overcoming or minimising these risks. We argue that introducing PAs in schools could enhance the risk of segregation of Roma pupils by impeding communication with 
peers and/or the teacher, as well as the risk of reduced engagement of the teachers in some aspects of their professional role. The risks could be prevented by introducing a competence-based framework for defining and understanding the roles of teachers and PAs, as scrutinised in the present paper. We argue that teachers and PAs need to perceive cultural differences in accordance with an ethnorelative worldview, and must develop every element of IC in its cognitive, affective and behavioural aspects. The engagement of PAs should be guided by the principles of inclusive education, assuring social participation and nurturing the cultural identity of Roma pupils. According to the proposed framework of IC, teachers should possess qualifications and should bear the main responsibility for providing support in the learning and social participation of Roma pupils, as well as in the cooperation with the Roma family. The activities of PAs should be planned and organised to complement, but by no means supplant, the activities of teachers. Cooperation between teachers and PAs needs to be based on the clear division of their professional tasks and responsibilities in achieving common goals, while support mechanisms should be provided by school leaders and other professionals.

\section{References}

Ang, S., Van Dyne, L., Koh, C., Ng, K. Y., Templer, K. J., Tay, C., \& Chandrasekar, N. A. (2007). Cultural intelligence: Its measurement and effects on cultural judgement and decision making, cultural adaptation and task performance. Management and Organization Review, 3(3), 335-371. doi: 10.1111/j.1740-8784.2007.00082.

Banks, A. J. (2006). Cultural Diversity and Education, Foundations, Curriculum, and Teaching. Boston: Pearson Education.

Bennett, M. J. (1986). Towards Ethnorelativism: A Developmental Model of Intercultural Sensitivity. In R. M. Paige (Ed.), Cross-cultural orientation: new conceptualizations and applications (pp. 27-70). Lanham, MD.: University Press of America.

Bennett, M. J. (1998). Intercultural communication: A current perspective. In M. J. Bennett (Ed.), Basic concepts of intercultural communication: Selected readings. Yarmouth, ME: Intercultural Press. Bennett, M. J. (2004). Becoming Interculturally Competent. In J. Wurzel (Ed.), Toward Multiculturalism: A Reader in Multicultural Education (pp. 62-77). Newton, MA: Intercultural Resource Corporation.

Bennet, M. J. (2011). A Developmental Models of Intercultural Sensitivity. Hillsboro \& Milano: Intercultural Development Research Institute.

Bennett, M. J. (2012). Roma Early Childhood Inclusion. The RECI Overview Report. Open Society Foundations, Roma Education Fund and UNICEF.

Bennett, J., \& Bennett, M. (2004). Developing intercultural sensitivity: An integrative approach 
to global and domestic diversity. In D. Landis, J. Bennett, \& M. Bennett (Eds.), Handbook of intercultural training (3rd ed.) (pp. 147-166). Thousand Oaks, CA: SAGE Publications.

Chen, G. M., \& Starosta, W. J. (1996). Intercultural Communication Competence: A Synthesis. Communication Yearbook, 19(1), 353-383.

Crozier, G., \& Davies, J. (2007). Hard to reach parents or hard to reach schools? A discussion of home-school relations, with particular reference to Bangladeshi and Pakistani parents. British Educational Research Journal, 33(3), 295-313.

Deardorff, D. K. (2006). Identification and assessment of intercultural competence as a student outcome of internationalization. Journal of Studies in International Education, 10(3), 241-266. doi: $10.1177 / 1028315306287002$

Đelić, J., Tomić-Najdanović, J., Nikolić, J., \& Džida, B. (2012). Empirijsko istraživanje: Procena kapaciteta i potreba učitelja za razvoj inkluzivnog obrazovanja [Empirical research: Assessment of teachers' capacities and needs for the development of inclusive education]. Beograd: Zavod za vrednovanje kvaliteta obrazovanja i vaspitanja i Savez učitelja Republike Srbije.

Desforges, C., \& Abouchar, A. (2003). The impact of Parental Involvement, Parental Support and family education on pupil achievements and adjustment: A literature review. Department for Education and Skills.

Duvnjak, N., Mihajlović, M., Skarep, A., Stojanović, J., \& Trikić, Z. (2010). Romski pedagoški asistenti i asistentkinje kao nosioci promena [Roma Pedagogical Assistants as Agents of Change]. Belgrade: OSCE Mission in Serbia.

European Roma Right Centre (2014). A Long way to Go: Overrepresentation of Roma Children in "Special Schools" in Serbia. Budapest: European Roma Right Centre.

Flecha, R., \& Soler, M. (2013).Turning difficulties into possibilities: engaging Roma families and students in school through dialogic learning. Cambridge Journal of Education, 43(4), 451-465.

Gay, G., \& Howard, T. C. (2000). Multicultural Teacher Education for the 21th Century. TheTeacher Educator, 36(1), 1-16.

Gimenez Adelantado, A., Piasere, L., \& Liegeois, J. P. (2002). The education of Gypsy childhood in Europe. Opre Roma.

Gomez, J.,\& Vargas, J. (2003). Why Roma do not like Mainstream Schools: Voices of a People without Territory. Harvard Educational Review, 73, 559-590.

Hammer, M. R. (2011). Additional cross-cultural validity testing of the Intercultural Development Inventory. International Journal of Intercultural Relations, 35(4), 474-487.

Institute for the Evaluation of Education Quality (2009). Evaluation study: The role of Pedagogical Assistants for the Support of Roma Students as a Systemic Measure for Improving the Education of Roma. Belgrade: Institute for the Evaluation of Education Quality.

Knowles, G., \& Holmstrom, R. (2013). Understanding Family Diversity and Home-School Relations. A guide for students and practitioners in early years and primary settings. London and New York: Routledge.

Kyuchukov, H. (2012). Roma mediators in Europe: A new council of Europe programme. 
Intercultural Education, 23(4), 375-378. http://dx.doi.org/10.1080/14675986.2012.724875

Leutwyler, B., Mantel, C., Petrović, D. S., Dimitrijević, B. M., \& Zlatković, B. (2014). Teachers’ Beliefs about Intercultural Education: Different Levels of Intercultural Sensitivity in Schooling and Teaching. Educational Research, 5(8), 280-289.

Lynch, K., \& Baker, J. (2005). Equality in education: an equality of condition perspective. Theory and Research in Education, 3(2), 131-164.

Macura-Milovanović, S. (2012). Crossed realities of Roma parents and non/Roma teachers: experiences from the action research study. In A. Heimgartner, U. Loch, \& S. Sting (Eds.), Empirische Forschung in der Sozialen Arbeit. Methoden und methodologische Herausforderungen [Empirical research in Social Work. Methods and Methodology Support] (pp. 275-287). Wien: OFEB Sektion Sozial padagogik, Universitat Graz, Bundesministerium fur Wissenschaft und Forschung. Macura-Milovanović, S., Pantić, N., \& Closs, A. (2012). Challenges in developing teacher preparation for working inclusively in contexts of increasingly diverse populations - the case of Serbia. Prospects, 42(1), 19-39.

McAllister, G. \& Irvine, J. J. (2000). Cross Cultural Competency and Multicultural Teacher Education. Review of Educational Research, 7o(1), 3-24.

Milovanović, I. (2014). Uloga pedagoškog asistenta u radu sa učenicima kojima je potrebna dodatna pomoć u učenju [The role of pedagogical assistant in work with pupils who need additional support]. (Master Thesis). University of Belgrade and University of Kragujevac.

Paige, R. M., Jacobs-Cassuto, M., Yershova, Y. A., \& DeJaeghere, J. (2003). Assessing intercultural sensitivity: an empirical analysis of the Hammer and Bennett Intercultural Development Inventory. International Journal of Intercultural Relations, 27(4), 467-486. doi: 10.1016/So147-1767(03)ooo34-8. Pravilnik o programu obuke za pedagoškog asistenta [Rulebook of training program for Pedagogical Assistant] (2010). Službeni glasnik RS, br. 11/2010.

Pravilnik o standardima kompetencija za profesiju nastavnika i njihovog profesionalnog razvoja [Rulebook of competency standards for teachers in Serbia] (2011). Službeni glasnik RS - Prosvetni glasnik, br. 5/2011.

Prechtl, E., \& Lund, A. D. (2007). Intercultural competence and assessment: Perspectives from the INCA Project. In H. Kotthoff, \& H. Spencer-Oatey (Eds.), Handbook of Intercultural Communication (pp. 467-49o). Berlin: Mouton de Gruyter.

Radovanović, S., \& Knežević, A. (2014). Popis stanovištva, domaćinstava i stanova 2011. u Republici Srbiji. Romi u Srbiji [2011 Census of Population, Households and Dwellings in the Republic of Serbia. Roma in Serbia]. Belgrade: Statistical Office of the Republic of Serbia.

Rus, C. (2004). The training of Roma school mediators and assistants. The Council of Europe. Rus, C. (2006). The situation of Roma school mediators and assistants in Europe. The Council of Europe.

Save the Children (2001). Denied a future? Summary. London: Save the Children.

Statistical Office of the Republic of Serbia (2014). Serbia Multiple Indicator Cluster Survey 2014.

Belgrade: UNICEF. 
Strategija za unapređivanje položaja Roma u Republici Srbiji [Strategy for the improvement of Roma position in Serbia (2009). Belgrade: The Ministry of Human and Minority Rights.

UNESCO and the Council of Europe (2014). Inclusion from the start: guidelines on inclusive early childhood care and education for Roma children.

Vandenbroeck, M. (2011). Diversity in Early Childhood Services. Encyclopaedia on Early Childhood Development.

Ward, C. (2001). The A, B, Cs of acculturation. In D. Matsumoto (Ed.), Handbook of Culture and Psychology (pp. 411-446). New York: Oxford University Press.

Westrick, J. (2004). The influence of service learning on intercultural sensitivity: A quantitative study. Journal of Research in International Education, 3(3), 277-299. doi: 10.1177/1475240904047356 Yuen, C. Y. M. (2010). Dimensions of diversity: Challenges to secondary school teachers with implications for intercultural teacher education.Teaching and Teacher Education, 26(3), 732-741.

Zakon o osnovama sistema obrazovanja $i$ vaspitanja [Law on the Foundations of the Education System] (2009). Službeni glasnik RS, br. 72/2009.

Zhang, J. (2014). The Review: The Intercultural Development Inventory Manual. Journal of Psychoeducational Assessment, 32(2), 178-183.

\section{Biographical note}

JeLENA STARČEvić is an assistant professor at the Faculty of Education, University of Kragujevac, Serbia, lecturing in the field of intercultural and inclusive education. Her research deals with the inclusive education in primary school as well as the conceptualization and assessment of individual differences in intercultural interaction.

Bojana Dimitrijević is a graduate teaching assistant at the Faculty of Education, University of Kragujevac, Serbia and a PhD candidate at the Department of Psychology, Faculty of Philosophy, University of Belgrade, Serbia. She is oriented towards the research fields of educational psychology, intercultural and inclusive education.

Sunčica Macura Milovanović is an associate professor of Inclusive education at the Faculty of Education, University of Kragujevac, Serbia. Her research interests are in inclusive education, the education of Roma children and intercultural education. 